\title{
Southeast Greenland Winter Precipitation Strongly Linked to the Icelandic Low Position
}

\author{
Mira Berdahl, ${ }^{\mathrm{a}, \mathrm{k}}$ Asa Rennermalm, ${ }^{\mathrm{a}}$ Arno Hammann, ${ }^{\mathrm{a}, \mathrm{l}}$ John MioduszWeski, ${ }^{\mathrm{b}}$ Sultan Hameed, ${ }^{\mathrm{c}}$

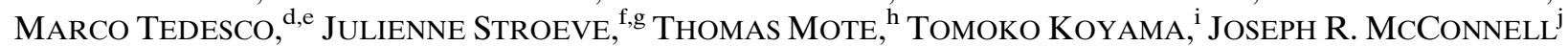 \\ ${ }^{a}$ Department of Geography, Rutgers, The State University of New Jersey, Piscataway, New Jersey \\ ${ }^{\mathrm{b}}$ Center for Climatic Research, University of Wisconsin-Madison, Madison, Wisconsin \\ ${ }^{\mathrm{c}}$ School of Marine and Atmospheric Sciences, Stony Brook University, Stony Brook, New York \\ ${ }^{\mathrm{d}}$ Lamont-Doherty Earth Observatory of Columbia University, Palisades, New York \\ ${ }^{\mathrm{e}}$ NASA Goddard Institute of Space Studies, New York, New York \\ ${ }^{\mathrm{f}}$ National Snow and Ice Data Center, University of Colorado, Boulder, Colorado \\ ${ }^{g}$ Centre for Polar Observation and Modelling, University College London, London, United Kingdom \\ ${ }^{\mathrm{h}}$ Department of Geography, University of Georgia, Athens, Georgia \\ i Department of Atmospheric and Oceanic Sciences, University of Colorado Boulder, Boulder, Colorado \\ ${ }^{\mathrm{j}}$ Desert Research Institute, Reno, Nevada
}

(Manuscript received 18 September 2017, in final form 12 January 2018)

\begin{abstract}
Greenland's largest precipitation flux occurs in its southeast (SE) region during the winter, controlled primarily by easterly winds and frequent cyclogenesis in the North Atlantic. Several studies have attempted to link SE Greenland precipitation to the North Atlantic Oscillation (NAO) but results are inconsistent. This work uses reanalysis, automatic weather station data, and regional climate model output to show that the east-west position of the Icelandic low is a better predictor of SE Greenland precipitation (average correlation of $r=-0.48$ in DJF) than climate indices such as the NAO $(r=-0.06$ in DJF). In years when the Icelandic low is positioned extremely west, moisture transport increases up to $\sim 40 \%$ (or up to $40 \mathrm{~kg} \mathrm{~m}^{-1} \mathrm{~s}^{-1}$ ) off the SE Greenland coast compared to when the low is in an extreme east position. Furthermore, in years when the Icelandic low is positioned extremely west, storm track density and intensity increase just off the SE coast of Greenland. Thus, the Icelandic low's longitudinal position dominates SE Greenland ice sheet's wintertime precipitation, a positive term in the ice sheet mass balance. Given SE Greenland's importance in the overall ice sheet mass balance, the position of the Icelandic low is therefore important for making projections of future sea level.
\end{abstract}

\section{Introduction}

The Greenland ice sheet (GrIS) presently contributes the greatest amount of meltwater to global sea level rise compared to any other individual source (Vaughan et al. 2013; Gardner et al. 2013), and projections indicate mass loss will increase at an accelerated pace (Rignot et al. 2011; Velicogna 2009). Between 1991 and 2015, the Greenland ice sheet was estimated to contribute $1.1 \mathrm{~cm}$ to global sea level rise (van den Broeke et al. 2016),

\footnotetext{
${ }^{\mathrm{k}}$ Current affiliation: Computational Physics and Methods (CCS-2), Los Alamos National Laboratory, Los Alamos, New Mexico.

${ }^{1}$ Current affiliation: Centro de Estudios Avanzados en Zonas Áridas, La Serena, Chile.
}

Corresponding author: Mira Berdahl, mira.berdahl@gmail.com while projections include an additional $8.1 \mathrm{~cm}$ by 2100 under the IPCC RCP 8.5 scenario (Bindschadler et al. 2013). The dominant mass loss process for the GrIS is shifting, at least temporarily, from being governed by ice dynamics to being dominated by surface mass balance processes van den Broeke et al. 2009; Enderlin et al. 2014). While sublimation, evaporation, and erosion/redistribution can be locally important (Lenaerts et al. 2012), the dominant component of the surface mass balance over Greenland is net snow accumulation (Koenig et al. 2016), followed by losses due to liquid runoff (Box 2013). Thus, it is of paramount interest to understand the controls of snow accumulation on the GrIS.

The large-scale spatial pattern of Greenland snow accumulation is well established with maximum snow accumulation along the southeast (SE) coast (Bales et al. 2009; Burgess et al. 2010; Cogley 2004; Hines and 
Bromwich 2008; Chen et al. 2011; Ohmura and Reeh 1991). Winter precipitation in SE Greenland is generally high due to prevailing easterly winds, frequent cyclogenesis in the region between Greenland and Iceland, the relatively low latitude, and the relatively high moisture availability from source air often originating over a warm ocean (Cappelen 2014; Hanna et al. 2006). In addition, the steep near-coastal mountains in the SE, which rise to more than $2000 \mathrm{~m}$, generate orographic enhancement of precipitation (Hanna et al. 2006). For example, Mernild et al. (2015) show that one SE Greenland station (Ikerasassuaq; $60.05^{\circ} \mathrm{N}, 43.15^{\circ} \mathrm{W}$ ) is strongly affected by synoptic cyclones passing close to Iceland, which typically produce a prevailing easterly airflow toward the SE coast of Greenland (Hanna et al. 2006).

A common approach to characterizing large-scale atmospheric circulation in the North Atlantic is through the North Atlantic Oscillation (NAO) index. The NAO index can be calculated a number of ways: as the leading mode in the empirical orthogonal function (EOF) of 500-mb geopotential heights in the Northern Hemisphere (Hurrell et al. 2003), as the leading EOF of the SLP over the North Atlantic region (Moore et al. 2013), or based on the sea level pressure difference between two fixed locations (e.g., Lisbon, Portugal, and Stykkisholmur, Iceland) (Hurrell 1995). Changes in the NAO have been shown to be associated with increases in cyclone activity off of the SE coast of Greenland (Serreze et al. 1997), which in turn affects precipitation rates in SE Greenland (Hanna et al. 2006). There have been a handful of studies relating Greenland precipitation to the NAO (e.g., Mosley-Thompson et al. 2005; Bromwich et al. 1999; Appenzeller et al. 1998a; Appenzeller et al. 1998b), showing that the NAO most strongly modulates precipitation in western and southern Greenland during winter.

Other teleconnection indices characterizing climate in the North Atlantic region, and Greenland in particular, are the Arctic Oscillation (AO), the Atlantic multidecadal oscillation (AMO), and the Greenland blocking index (GBI). Related to the NAO, the AO is a large-scale mode of climate variability, characterized by winds circulating counterclockwise around the Arctic at around $55^{\circ} \mathrm{N}$. The sign of the AO determines the strength of the polar vortex, and thus influences whether cold Arctic air reaches midlatitudes or remains at higher latitudes. The AMO is the leading low-frequency (multidecadal) mode of sea surface temperature (SST) variability across the North Atlantic (Arguez et al. 2009). The AMO is considered a good proxy for oceanic structure and circulation (Hanna et al. 2009) and has been shown to influence southern Greenland climate (Arguez et al. 2009). There is also evidence that variability associated with the AMO may be related to an oceanic response to the NAO ( $\mathrm{Li}$ et al. 2013; Sun et al. 2015). The GBI is defined as the mean $500-\mathrm{mb}$ height over the Greenland area $60^{\circ}-80^{\circ} \mathrm{N}, 20^{\circ}-80^{\circ} \mathrm{W}$. It is equivalent to the NAO-AO index but emphasizes the northern center of the NAO dipole pattern (Hanna et al. 2013). The east Atlantic (EA) and Scandinavian (SCA) patterns are the second and third leading teleconnections in the North Atlantic region (following the NAO), each explaining 15\%$20 \%$ of the winter sea level pressure field (Moore et al. 2013). The strength of the EA has been shown to modulate the latitude of the center of the Icelandic low, while the strength of the SCA dictates the longitude of the center of the Icelandic low (Moore et al. 2013). This has consequences for the North Atlantic climate and Greenland in particular. For example, Moore et al. (2011) showed that the EA mode was partly responsible for an anomalously positive NAO in the winter of 2007 , which forced more frequent barrier winds along the southeast coast of Greenland (Renfrew et al. 2008; Petersen et al. 2009).

An analysis of empirical orthogonal functions (EOFs) carried out for coastal precipitation sites and ice core records shows that the first EOF (which represents about $46 \%$ of the squared covariance) is linked to NAO and AMO variability and responds inversely to the GBI with an $\sim 6-y r$ lag (Mernild et al. 2015). This study also finds that, as a whole, ice sheet precipitation records exhibit decreasing trends since the 1960s, while the coastal stations show increasing trends in precipitation. In contrast to Mernild et al.'s (2015) study, Hanna et al. (2006) find no significant correlation between the winter NAO index and an extended accumulation time series in SE Greenland $(r=-0.09)$ and a relatively weak relationship with winter precipitation in Tasiilaq, a coastal town in the SE $(r=-0.22)$.

Bakalian et al. (2007) argue that a better understanding of climatic events in the North Atlantic can be obtained by analyzing the pressure centers of the Icelandic low and Azores high as uncoupled centers of action (rather than combined as in the NAO index). The authors support this hypothesis by showing that it is the latitude of the Icelandic low that gives rise to the formation of Greenland tip jets (brief, localized, and intermittent northwesterly winds that descend on the eastern side of Greenland's southern tip, typically in winter). Similarly, the longitude of the Icelandic low is the dominant influence of the position of the north wall of the Gulf Stream, perhaps through changes in wind stress in the Labrador Sea region (Hameed and Piontkovski 2004; Sanchez-Franks et al. 2016). Further, the climate records from the Greenland Ice Sheet Project (GISP2) ice core suggest a complex relationship with the NAO that has been proposed to be related to the location of the Icelandic low (Dawson et al. 2007). Icelandic low pressure can also have farther-reaching 


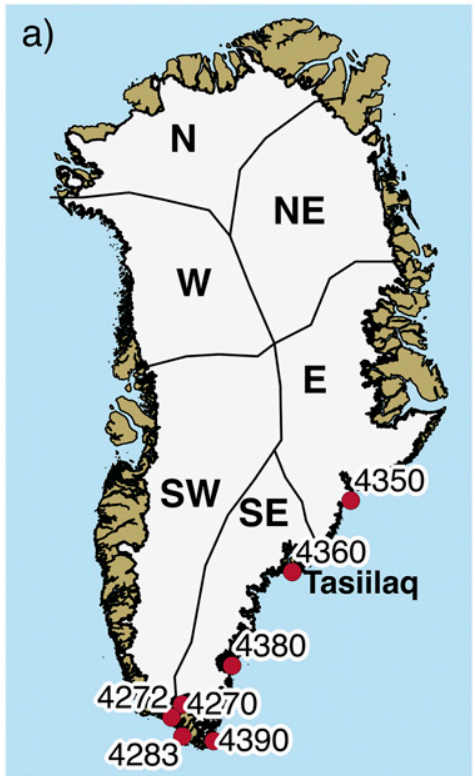

b)

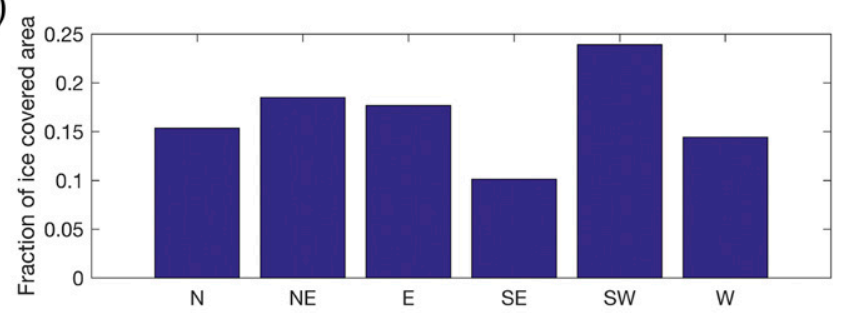

c)

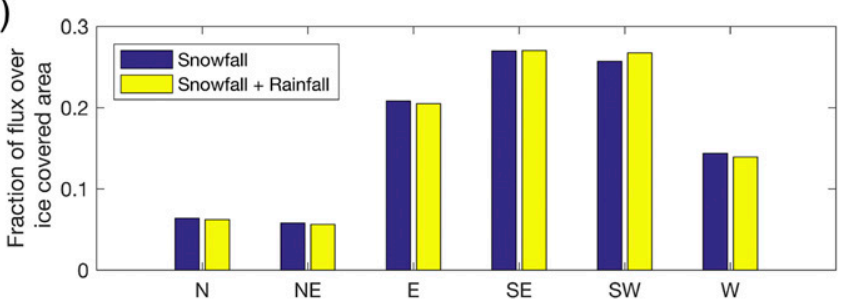

FIG. 1. (a) Map of Greenland regions (N, W, SE, SE, E, and NE) and locations of automatic weather stations used in this study, (b) MAR ice-covered area fraction of each region based on regions shown in (a), and (c) MAR precipitation fluxes in each region. The greatest flux of snowfall and rainfall is in the SW and SE, but per unit area the fluxes are larger in the SE.

effects. For example, it has been shown that the interannual variation of sea level pressure of the Icelandic low influences winter air temperature in the Gulf of Lion (in the northwest Mediterranean Sea), which is considered a proxy for formation of Mediterranean Intermediate Water (Jordi and Hameed 2009).

This study, building on the findings of Bakalian et al. (2007) and Moore et al. (2013), expands on previous studies on controls of Greenland precipitation by examining six different teleconnection indices (the NAO, AO, AMO, GBI, EA, and SCA) as well as the latitude, longitude, and central pressure of the Icelandic low with emphasis on the period between 1958 and 2012. Precipitation measurements along the Greenland coast are obtained from automatic weather station (AWS) data from the Danish Meteorological Institute (Cappelen 2014). Moreover, spatially distributed precipitation fields over the entirety of Greenland are obtained from the regional climate model Modèle Atmosphérique Régional (MAR) (Lefebre et al. 2005; Fettweis et al. 2013). Modeled and observed precipitation are used to place SE Greenland winter precipitation in geographic and seasonal context. The relationships between Tasiilaq $\left(65.60^{\circ} \mathrm{N}, 37.63^{\circ} \mathrm{W}\right)$ precipitation observations and the six selected climate indices and the three new Icelandic low indices (latitude, longitude, and pressure) are then quantified. The Icelandic low's longitudinal position proves to have the strongest relationship to Tasiilaq winter precipitation. Next, the extent to which the observations at the coastal town of Tasiilaq are representative of SE Greenland at a regional scale is assessed. Finally, reanalysis is used to link winter precipitation in SE Greenland to large-scale atmospheric conditions and North Atlantic storm tracks in years when the Icelandic low is in extreme positions. This is the first quantitative study to consider Icelandic low characteristics to explain Greenland precipitation.

\section{Data}

Monthly precipitation, temperature, and pressure data from coastal automatic weather stations (AWS) were obtained from the Danish Meteorological Institute (DMI) (Cappelen 2014). The length of the station time series varies as does the number of stations available in each region (demarked in Fig. 1). The numbers of stations available for each region were 19 for the southwest, 11 for the southeast, 5 for the east, 2 for the northeast, 3 for the north, and 1 for the west region. The stations measure solid precipitation in millimeters of water equivalent (w.e.) by melting the snow prior to measuring.

Outputs from the 20-km resolution MAR version 3.5.2 model, a coupled land-atmosphere regional climate model, were used for an AWS station data comparison and regional assessment of precipitation (Fettweis 2007; Gallée et al. 2005; Lefebre et al. 2005). A detailed 
description of the atmospheric component of MAR can be found in Gallée and Schaves (1994) and Gallée (1995). MAR's snow model is described in Reijmer et al. (2012). MAR's simulation domain covers Greenland and the nearshore surrounding areas. Data for the period 1958-2012 were used here. The MAR model version was forced with the National Centers for Environmental Prediction-National Center for Atmospheric Research (NCEP-NCAR; Kalnay et al. 1996) output at the lateral boundaries and ocean. In a comparison study of MAR 3.5.2 forced with several different reanalysis products and Greenland ice sheet weather station data, Fettweis et al. (2017) found that MAR 3.5.2 forced by NCEPNCAR or ERA-Interim were the best forcings. ERAInterim forcings are only available since 1979 and therefore not suitable for this study. MAR outputs have been validated against satellite and in situ data (e.g., Lefebre et al. 2005; Fettweis et al. 2011) and have been used in many studies simulating surface mass balance and atmospheric circulation near Greenland (e.g., Tedesco et al. 2013; Franco et al. 2012; Fettweis 2007; Andersen et al. 2015). MAR was recently found to overestimate accumulation rates by up to $1 \mathrm{~m}$ w.e. $\mathrm{yr}^{-1}$ in some parts of SE Greenland as compared to airborne Snow Radar data collected by NASA's Operation IceBridge from 2009 to 2012 (Koenig et al. 2016). Fettweis et al. (2017) showed a cold bias in MAR 3.5.2 compared to data from eight in situ weather stations. The cold bias in the model is likely partly due to a negative bias in downward longwave radiation as a result of a lack of clouds and overestimated albedo; however, some of this is offset by an overestimated incoming shortwave radiation (Fettweis et al. 2017). MAR forced with NCEPNCAR data overestimates snow accumulation in the SE, but correlates well $(r=0.92)$ with data derived from ice core observations (Fettweis et al. 2017).

To investigate large-scale wind and humidity patterns and their relation to SE Greenland precipitation, the Japanese 55-year Reanalysis (JRA-55) product was used. This reanalysis product was chosen since it is a modern third generation product with a long time period coverage (Ebita et al. 2011). Monthly average water vapor transport was downloaded from https://rda.ucar. edu/\#!lfd?nb5y\&b5proj\&v5JMA.

Reanalysis data run from January 1958 to December $2012(57 \mathrm{yr})$ and have a spatial coverage of $1.25^{\circ}$ latitude $\times 1.25^{\circ}$ longitude on a global grid. Reanalysis sea level pressure data (4 times daily) from the NCEPNCAR (Kalnay et al. 1996) were used for the storm track analysis. Three characteristics of the Icelandic low were used in this analysis: latitude, longitude, and central pressure. These attributes were calculated using monthly gridded SLP data from NCEP-NCAR reanalysis (Kalnay et al. 1996), as described in Hameed and Piontkovski (2004). Details on these calculations can be found in section 3 .

Six indices often used to explain large-scale atmospheric controls on Greenland climate are used, including the NAO index, the AO index, the AMO index, and the GBI. This study used the NAO index provided by Climatic Research Unit at the University of East Anglia (Jones et al. 1997), which uses the pressure difference between Iceland and the Azores (http:// www.cru.uea.ac.uk/cru/data/nao/). The AO index data were obtained from NOAA at http://www.cpc.noaa.gov/ products/precip/CWlink/daily_ao_index/ao_index.html. Both the AMO (Enfield et al. 2001) and the GBI (Hanna et al. 2013) index values were downloaded from NOAA (https://www.esrl.noaa.gov/psd/data/timeseries/AMO/ and https://www.esrl.noaa.gov/psd/data/timeseries/daily/GBI/). The EA and SCA were both downloaded from the National Weather Service Climate Prediction Center website (http://www.cpc.ncep.noaa.gov/data/teledoc/ea.shtml and http://www.cpc.ncep.noaa.gov/data/teledoc/scand.shtml). It must be noted that the teleconnection indices have been derived from different data sources (i.e., AO, AMO, and GBI; EA and SCA from NCEP-NCAR reanalysis; NAO from station observations) and some are calculated as modes from EOF analysis (i.e., AO, AMO, EA, SCA) while others are differences or anomalies (i.e., GBI and NAO). However, the EOF-based and stationbased NAO indices are well correlated $(r=0.82)$ so use of either index is justifiable.

\section{Methods}

The study period was 1958 to 2012, during which data are available for DMI AWS at Tasiilaq, the three Icelandic low characteristics (latitude, longitude, and pressure), all climate indices, and the MAR 3.5.2 outputs. AWS stations in the SE were considered viable if they had at least $20 \mathrm{yr}$ (total) of data. Therefore, the following stations were used in this study: 4390, 4380, 4360, 4350, 4270, 4272, and 4283 (see Fig. 1a).

The DMI AWS data were bias-corrected for windinduced undercatch. Specifically, the rating curves previously applied to Greenland data by Yang et al. (1999) were used according to the following procedure: The curve for rain is applied to a daily precipitation amount if all temperature measurements of that day fall above $0^{\circ} \mathrm{C}$; the curve for snow is applied if all temperatures fall below $0^{\circ} \mathrm{C}$; and the curve for mixed precipitation is applied in the remaining cases. The curves are fitted to the wind speed, which is first reduced from the height of the anemometer to that of the rain gauge using a logarithmic wind profile and two different roughness lengths for 

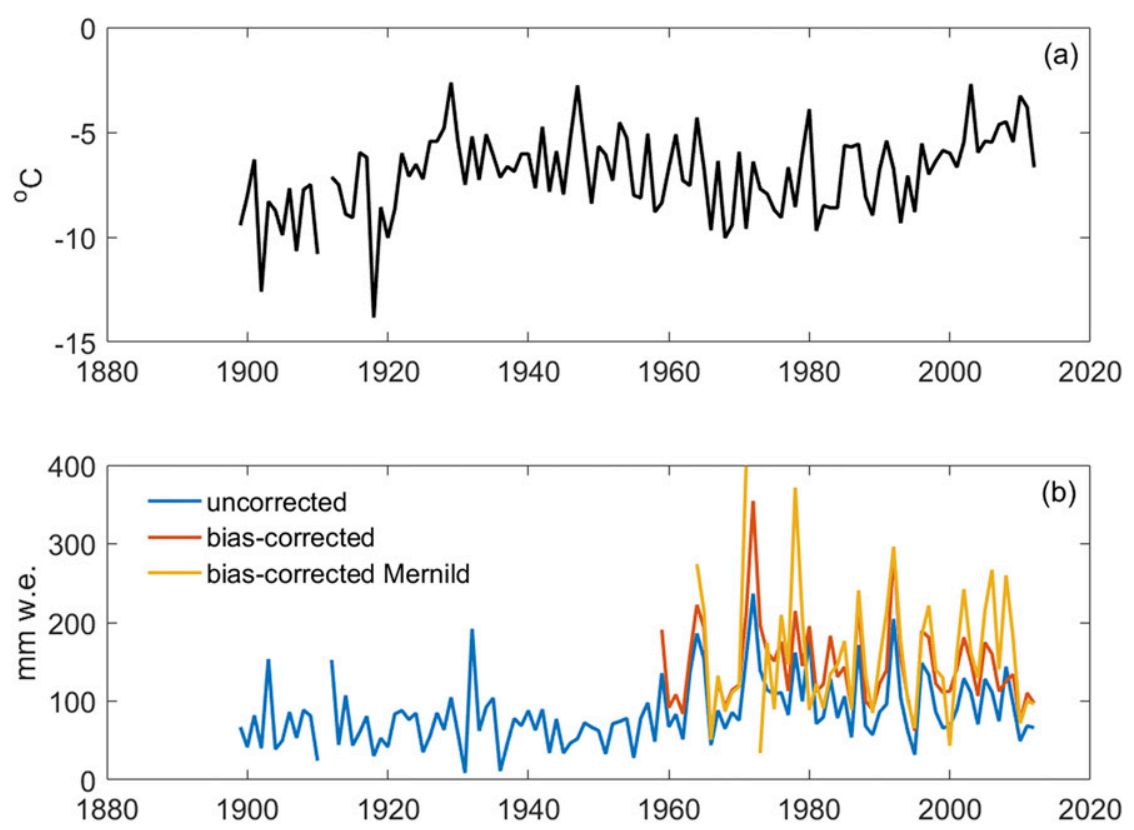

FIG. 2. (a) Tasiilaq station DJF (winter average) temperature and (b) precipitation (mm w.e.). Bias-corrected data are also shown beginning in 1958, when wind data become available at the location. The Mernild et al. (2015) bias correction is also shown for transparency.

winter (September-May; $0.01 \mathrm{~m}$ ) and summer months $(0.03 \mathrm{~m})$. Sensor heights from Yang et al. (1999) are used, and for stations where this information is not available, $3 \mathrm{~m}$ and $10 \mathrm{~m}$ are assumed for rain gauges and anemometers, respectively. For wind speeds above $6.5 \mathrm{~m} \mathrm{~s}^{-1}$ the correction factor remains the same as for $6.5 \mathrm{~m} \mathrm{~s}^{-1}$. Discrepancies between the corrected precipitation records calculated here and the Mernild et al. (2015) corrected precipitation data were found at the Tasiilaq site (Fig. 2). For example, in the case of the highest winter precipitation record in 1971/72, Mernild et al. (2015) reported a value of $1035.5 \mathrm{~mm}$ w.e., almost 3 times the value of this dataset's highest winter precipitation record at Tasiilaq of $350 \mathrm{~mm}$ w.e. This is largely a result of using different bias-correction techniques, so both raw and bias-corrected data (Fig. 2) are shown for transparency.

Greenland was divided into five regions based on the major ice sheet topographical divides, hereafter referred to as N (North), NW (Northwest), W (West), SW (Southwest), SE (Southeast), and W (West) (Fig. 1). Spatially averaged values over these five regions of liquid and solid precipitation and runoff from the ice sheet were calculated using MAR outputs. As a comparison with the model data, seasonal and annual precipitation averages were calculated by using all stations in each region, ignoring missing values. In the SE, the Tasiilaq station had the longest (beginning before 1900) and a nearly continuous record of precipitation. Consequently, this station was used as a representation of the SE region. This is further justified in the results and analysis section.

To determine the degree to which the Tasiilaq station is representative of the other DMI AWS stations in SE Greenland, correlation analysis was performed in the overlapping time periods. Furthermore, to examine the spatial representativeness of the Tasilaq location, Spearman correlation coefficients were calculated between DJF precipitation in the entire MAR domain and both (a) Tasiilaq DJF bias-corrected precipitation and (b) the simulated DJF precipitation values at the closest MAR grid cell to Tasiilaq. Statistical significance at the $10 \%$ level was determined with a bootstrap method testing the null hypothesis of each MAR grid cell having random precipitation time series. For each grid cell, MAR precipitation was permutated 100 times and each permutation was correlated with data from the Tasiilaq location (station data and MAR data, respectively). From the resulting distribution of Spearman correlation coefficients, the 5th and 95th percentiles were extracted to identify the $10 \%$ two-sided significance level. The same methodology was applied to examine the spatial region of influence of other relevant stations and Icelandic low characteristics.

Three Icelandic low characteristics (latitude, longitude, and pressure) were calculated following the 
methods in Bakalian et al. (2007) and Hameed and Piontkovski (2004). By examining monthly SLP since 1948, the latitude-longitude domain over which the Icelandic low occurs was identified. The pressure index of the Icelandic low is defined as an area-weighted pressure departure from a threshold value over its domain (I, J). The pressure index is thus a measure of the anomaly of atmospheric mass over the sector (I, J). The location indices give pressure-weighted mean latitudinal and longitudinal positions of the low. The spatial domain covered by these "objective" indices was $40^{\circ}-75^{\circ} \mathrm{N}, 90^{\circ} \mathrm{W}-20^{\circ} \mathrm{E}$ (Bakalian et al. 2007). Note that the domains of the Azores high and Icelandic low overlap and the threshold that separates them is $1014 \mathrm{mb}$. If the monthly averaged pressure in a grid box is greater than $1014 \mathrm{mb}$, it is assigned to the Azores high, and for a lower value to the Icelandic low. Given that the North Atlantic is a region with the heaviest density of sea level pressure observations in comparison with other ocean basins, one can expect different reanalysis products (which assimilate the observations) to be more in agreement in this region than elsewhere. Therefore the use of NCEP-NCAR reanalysis data to calculate the Icelandic low index is justifiable, although a future study comparing indices of the Icelandic low and Azores high derived from different reanalysis products would be a useful exercise.

To evaluate the relationship between Tasiilaq precipitation and the three Icelandic low characteristics and the six climate indices, both Pearson and Spearman correlation methods (Hauke and Kossowski 2011) were used and were found to produce very similar results. Therefore, only Pearson correlation analysis results are reported. Correlations were calculated between detrended indices and DJF seasonal precipitation means and monthly precipitation means. To illuminate if precipitation in some decades more strongly covaried to certain indices than others, correlations between detrended DJF precipitation and index data were calculated for 10-yr-long data records in a moving window through the 1959-2012 study period.

Statistically significant relationships were identified between measured precipitation and one or more of the seven climate indices and quantities (i.e., the three Icelandic low characteristics and the four climate indices). To explain these significant relationships, an analysis of wind and humidity patterns around Greenland was performed. Specifically, DJF composites of SLP and water vapor transport are shown for years where the climate indices with statistically significant correlations to SE Greenland precipitation were extreme, here defined as being above or below 1 standard deviation (SD).

To extract cyclone tracks, the algorithm by Serreze et al. (1997) was applied to NCEP-NCAR reanalysis data. In this algorithm, the cyclone center was defined as when the SLP was at least $1 \mathrm{hPa}$ lower than the adjacent grid points. Given a maximum search distance and an allowable pressure difference, the tracking algorithm examined if a target cyclone moved in sequential time steps. To select robust cyclone systems in the Arctic $\left(60^{\circ}-90^{\circ} \mathrm{N}\right)$, only cyclones satisfying the following three criteria were considered to be valid: (i) cyclones must last more than $24 \mathrm{~h}$, (ii) cyclones must not be stationary, and (iii) a cyclone must deepen at least $2 \mathrm{hPa}$ during its life cycle (Serreze and Barrett 2008). The target cyclones from December to February for this study were determined from the period when each system dissipated: only systems that generated before the end of February and dissipated after 1 December were chosen. Also, target systems were determined from its dissipated location, where longitude was between $0^{\circ}$ and $75^{\circ} \mathrm{W}$, and latitude was higher than $55^{\circ} \mathrm{N}$. Koyama et al. (2017) also compared detected cyclones using NCEP-NCAR, MERRA, and ERA-Interim, and found that similar features can be observed among them, and therefore the data source used for this methodology does not play a major role in their detection.

Similar to the analysis with wind and moisture composites, DJF composites of storm tracks were calculated for years when the climate indices with statistically significant correlations to SE Greenland precipitation were extreme [above (east) or below (west) 1 SD]. The storm track density (number of storms per unit area) was calculated and weighted by the local Laplacian at each cyclone center (which is proportional to the geostrophic relative vorticity and directly indicates the cyclone intensity) (Murray and Simmonds 1991). To smooth the relatively coarse data, a Gaussian kernel was placed at every storm track location. The difference between extreme east and west years was then taken. Areas of significant difference between the years were calculated at the $5 \%$ significance level. To find the $5 \%$ significance, the above algorithm was repeated 1000 times on random sets of years between 1958 and 2012. The $p$ value was given by the cumulative distribution function of the bootstrapped differences at each location using the true value as the argument.

\section{Results and analysis}

\section{a. General precipitation patterns of Greenland}

MAR simulations are in agreement with previously published results (Tedesco et al. 2013; Franco et al. 2012) and show that the SE regions have the largest average annual snow and rain flux compared to all other regions (Fig. 1). Despite the fact that the SE area is only slightly greater than $10 \%$ of the total Greenland ice-covered (ice 
TABLE 1. Table of mean annual and seasonal precipitation ( $\mathrm{mm}$ w.e.) for all regions. Mean annual values are for the entire record (all months from 1958 to 2012, except starting in 1959 for DJF). Not all stations necessarily cover the entire record period.

\begin{tabular}{lrrrrrr}
\hline & SW & SE & E & NE & N & W \\
\hline Number of available stations & 19 & 11 & 5 & 2 & 3 & 1 \\
Mean annual precipitation (mm w.e.) & 74 & 124 & 66 & 38 & 27 & 44 \\
Mean DJF precipitation (mm w.e.) & 78 & 143 & 81 & 42 & 24 & 41 \\
Mean MAM precipitation (mm w.e.) & 59 & 113 & 61 & 35 & 21 & 31 \\
Mean JJA precipitation (mm w.e.) & 68 & 105 & 46 & 29 & 31 & 40 \\
Mean SON precipitation (mm w.e.) & 91 & 135 & 75 & 43 & 30 & 66 \\
\hline
\end{tabular}

sheet and peripheral glaciers) area and the smallest of the five regions (Fig. 1b), both snowfall and rainfall count for about $30 \%$ of the total precipitation for all of Greenland (Fig. 1c). SE Greenland precipitation exceeds all other areas including the (largest) SW region.

Average annual precipitation amounts for the five regions calculated with the DMI station data confirm the pattern identified with MAR. Similar to MAR, SE Greenland receives the greatest amount of precipitation (an average of $124 \mathrm{~mm}$ w.e.) followed by the SW, which receives about two-thirds of that (Table 1). Although the rankings vary, both MAR and DMI observations show that the N and NW regions receive the least precipitation. When precipitation is averaged for each season, the SE region dominates followed by the $\mathrm{E}$ and SW regions, depending on the season (Table 1). In most regions, the majority of precipitation falls in winter (DJF) and fall (SON) when cyclones are frequent in the North Atlantic. Thus, coastal station data agree with the MAR model that the relative contribution of the SE is greatest compared to the rest of Greenland, and that most precipitation occurs in the SE in winter.

\section{b. Controls of Tasiilaq precipitation}

Since SE Greenland receives the largest amount of winter precipitation, it plays a large role in contemporary surface mass balance (van den Broeke et al. 2016). Moreover, the linkage between climate drivers and precipitation in this region is poorly understood. Henceforth, we focus on characterizing and understanding the controls of southeast Greenland winter precipitation. DJF temperature and precipitation observations for the Tasiilaq station are nearly continuous, extending back to before 1900 (Fig. 2). This record is the longest and most complete of all DMI SE stations. In Tasiilaq, the coldest winters occurred in the late nineteenth century, and in the first few decades of the twentieth century (Fig. 2a). This was followed by warming in the 1920s and 1930s. These warmer winters slowly trend colder from the 1930s to the 1970s, followed by a statistically significant $(p<0.05)$ warming starting in the 1980s and continuing until the end of our data period. The latter correlation was tested for autocorrelation using Durbin-Watson (e.g., Wilks 2011) and none was found. Winter precipitation at Tasilaq is relatively consistent from before 1900 to about 1960 (Fig. 2b). At 1960 there appears to be a shift toward more precipitation, followed by a decrease beginning in the 1980s. However, the decrease in winter precipitation from 1980 to 2012 is not statistically significant $(p>0.05)$. Extreme winter precipitation maxima are generally clustered after 1960, with the largest occurring in the winter of 1971/72, with a bias-corrected value of roughly $350 \mathrm{~mm}$ w.e.

Time series of Tasiilaq precipitation and the three characteristics of the Icelandic low (latitude, longitude, pressure) and six relevant teleconnection indices (NAO, AO, AMO, GBI, EA, SCA) show distinct variability in the time period 1958-2012 (Fig. 3, Table 2). No significant trends in Tasiilaq precipitation were found, temperature generally increased significantly $(p<0.05)$ from 1980 to 2012. Among the Icelandic low characteristics and the six teleconnection indices, only the AMO exhibited a significant $(p<0.05)$ trend in this period. While autocorrelation may inflate degrees of freedom and test statistics (and lower $p$ values), the Durbin-Watson test (e.g., Wilks 2011) revealed that only the GBI index data are autocorrelated $(p<0.05)$. Given that GBI expressed no significant trend, no adjustments to the statistical significance test were made.

Of the six climate indices and Icelandic low characteristics, the longitude of the Icelandic low was the most strongly correlated $(r=-0.42, p<0.01)$ to DJF Tasiilaq precipitation (Fig. 4), meaning that when the Icelandic low is farther to the west more precipitation falls on SE Greenland than when it is located farther east. For example, examination of a few extreme precipitation events $(1965,1973,1988$, and 1993) seen in Fig. 2 shows that these occur in years when the Icelandic low is located in a farther west position than normal (data not shown). The GBI and AMO also show significant correlations with Tasiilaq precipitation in DJF, but at a larger significance level $(r \cong-0.28, p<0.05)$. In contrast, correlation between winter precipitation at Tasiilaq and NAO $(r=-0.06)$ is insignificant and weaker than that found by Hanna et al. (2006) $(r=-0.22)$ for a shorter time period. While the NAO and GBI index are strongly correlated $(r=-0.84)$, Tasiilaq precipitation is better predicted by the GBI $(r=-0.28)$ than the NAO $(r=-0.06)$ suggesting that some of the mechanisms behind the covariability of the NAO and GBI have minor influence at the Tasilaq station.

The moving window analysis (Fig. 5) shows that the controls of precipitation in the SE are not stable and are subject to change in strength depending on the time 


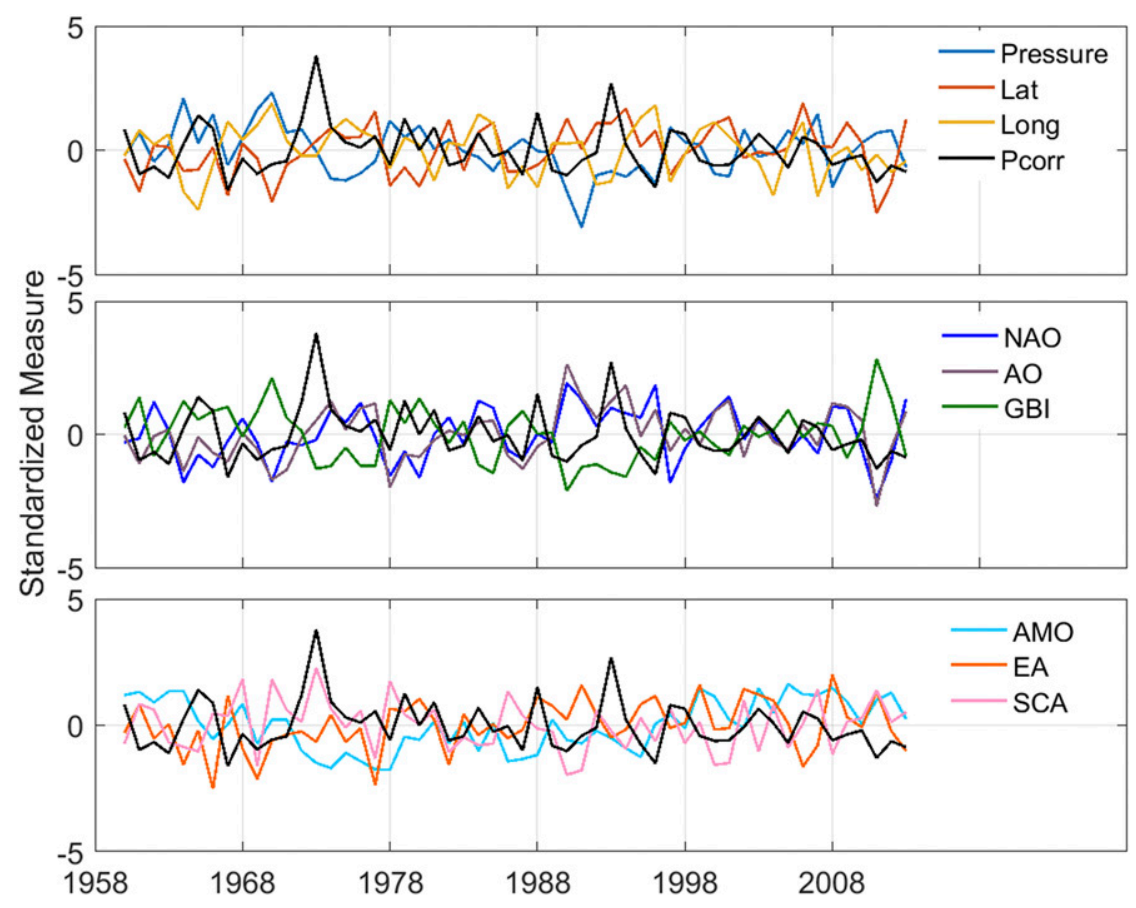

FIG. 3. DJF Tasiilaq precipitation (black line shown in all panels) and all metrics used to correlate to bias-corrected precipitation. Every metric has been standardized (subtract the mean and divide by standard deviation). Metrics include (top) Icelandic low pressure, latitude, longitude, and (middle) the NAO, AO, GBI and (bottom) AMO, EA, and SCA indices.

frame that is considered. The strongest correlation in the moving window analysis is between precipitation and longitude of the Icelandic low, peaking at $r=-0.95$. Correlations between longitude of the Icelandic low and Tasiilaq precipitation vary from very strong $(r$ peaks locally at -0.89 ) in the mid-1960s to early 1970 s to weak through the 1980s, and back to strong in the 1990s until the early 2000s ( $r$ peaks locally at -0.95$)$. Other indices show more transient, less sustained, significant correlations, which translates to a lower number of $10-\mathrm{yr}$ windows that are statistically significant for each index

TABLE 2. Mean and standard deviation of all indices used in this study for comparison to Greenland precipitation. These data are complementary to Fig. 3, although the mean shown here is for nonstandardized indices.

\begin{tabular}{lrc}
\hline \multicolumn{1}{c}{ Index } & Mean & Standard deviation \\
\hline Pressure of low $(\mathrm{mb})$ & 1005.8 & 0.002 \\
Latitude of low $\left(^{\circ}\right)$ & 59.3 & 3.211 \\
Longitude of low $\left(^{\circ}\right)$ & 328.5 & 5.520 \\
NAO & 0.3 & 1.401 \\
AO & -0.3 & 1.146 \\
GBI & 5128 & 5.581 \\
AMO & -0.1 & 0.179 \\
EA & -0.3 & 0.837 \\
SCA & -0.14 & 0.655 \\
\hline
\end{tabular}

(Fig. 5 inset). The longitude of the Icelandic low is significant for the longest period of time (20 periods), followed by 10 periods for GBI. The latitude of the Icelandic low is strongly negatively correlated to precipitation in the late 1990s, but in the late 2000s becomes significantly positively correlated but only for a very brief period (three 10-yr windows). The NAO is only briefly significantly correlated to SE Greenland precipitation in the late 1990s. Similar transient correlations have been found between temperature and teleconnection indices (Hanna et al. 2013).

\section{c. Tasiilaq and the broader SE regional precipitation}

To understand if the relationship between Tasiilaq DJF precipitation and the Icelandic low longitude can be generalized over a larger area, we first have to establish how representative Tasiilaq precipitation is of the SE region in general. To do this, DJF precipitation from SE stations with at least 20 years of data (stations considered viable are 4390, 4380, 4350, 4270, 4272, and 4283) are compared to Tasiilaq (4360). Average correlation between Tasiilaq DJF precipitation and all of these stations are $r=0.38$ and all correlation coefficients are statistically significant $(p<0.1)$ (Table 3). Hanna et al. (2006) also found that SE Greenland winter accumulation in ECMWF is highly correlated with 


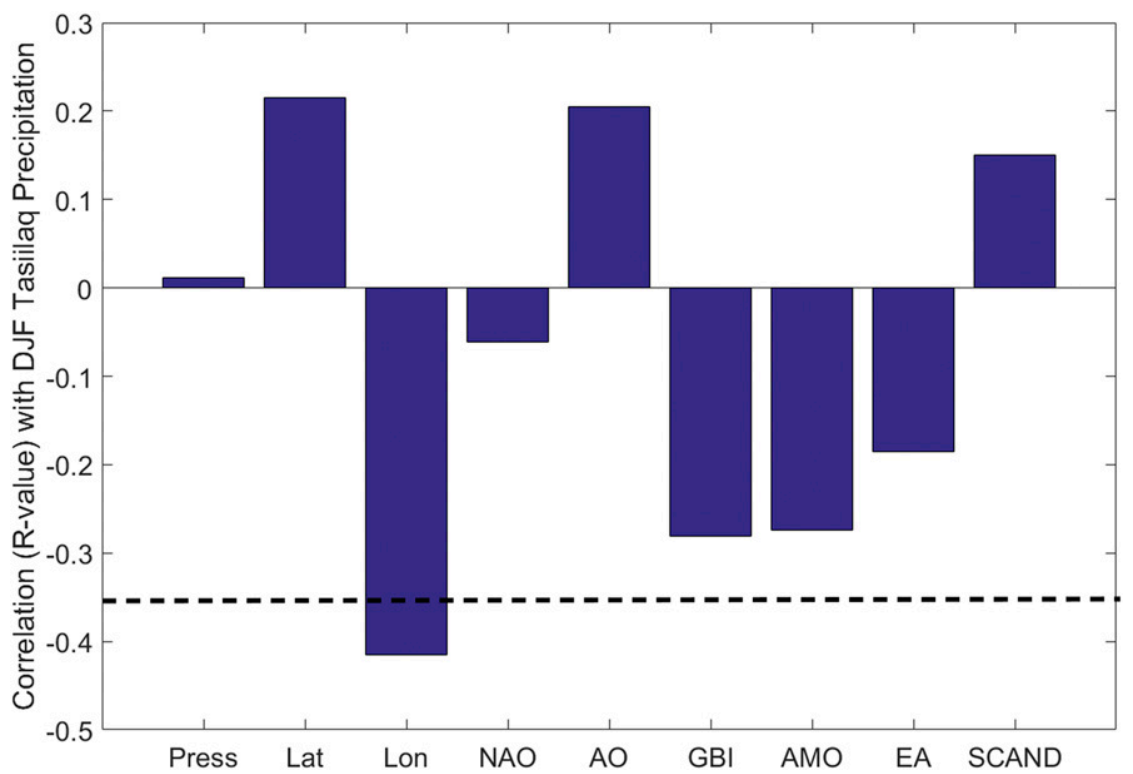

FIG. 4. Bulk correlations from 1958-2012 of DJF Tasiilaq precipitation with all six climate indices and the three Icelandic low characteristics. The black dashed line indicates statistical significance $(p<0.01)$.

Tasiilaq precipitation. The coefficient of determination $\left(r^{2}\right)$ varies between 0.08 and 0.22 , meaning that only a maximum of $22 \%$ of the interannual variability in Tasiilaq DJF precipitation can be explained by neighboring stations, suggesting that the controls DJF precipitation may differ between stations. Indeed, a distinction in the controls of the Icelandic low longitude on precipitation based on geographic location is found. That is, stations located on the east coast (ID codes beginning in 43XX) exhibit much stronger correlation ( $r$ on average -0.48 ,

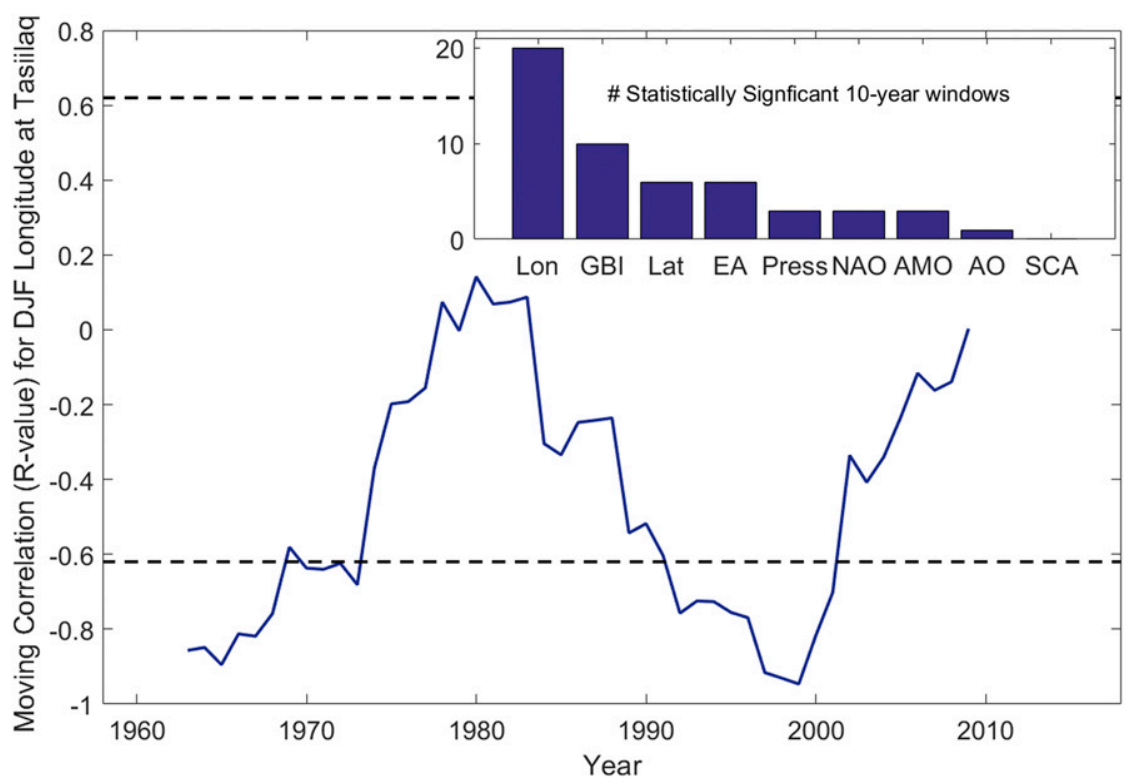

FIG. 5. Moving correlation (10-yr window) for Icelandic low DJF longitude at Tasiilaq. Dashed lines indicate level of significance. Values between the dashed lines are not statistically significant. Values outside of these bounds are statistically significant at the $95 \%$ level. Inset bar chart shows the number of $10-\mathrm{yr}$ windows that are statistically significant for all indices considered. 
TABLE 3. Correlation of other SE DMI stations with Tasiilaq DJF bias-corrected precipitation, for stations considered viable (those with at least 20 years of data).

\begin{tabular}{llccc}
\hline \hline Station ID & \multicolumn{1}{c}{ Station location relative to Tasiilaq } & $\begin{array}{c}\text { \% data coverage } \\
\text { (from 1958 to 2012) }\end{array}$ & $\begin{array}{c}\text { Correlation with } \\
\text { Tasiilaq }(r \text { value) }\end{array}$ & $\begin{array}{c}\text { Significance of correlation with } \\
\text { Tasiilaq }(p \text { value) }\end{array}$ \\
\hline 4360 & Tasiilaq & 98 & 1 & 0 \\
4390 & South & 76 & 0.31 & 0.05 \\
4380 & South & 38 & 0.41 & 0.07 \\
4350 & North & 38 & 0.43 & 0.05 \\
4270 & South and just west of south Greenland tip & 89 & 0.29 & 0.05 \\
4272 & South and just west of south Greenland tip & 95 & 0.47 & 0.0004 \\
4283 & South and just west of south Greenland tip & 40 & 0.39 & 0.07 \\
\hline
\end{tabular}

$p<0.05$ ) than those located on the southwest tip (station IDs coded as $42 \mathrm{XX}$ ), which have low, insignificant correlations $(p>0.05)$ with Icelandic low longitude (see station locations in Fig. 1). Station 4350, which is the next station north of Tasiilaq, is not correlated with the longitude of the Icelandic low. This pattern is further supported by the spatial correlation map (Fig. 6) showing correlations between the Icelandic low and modeled precipitation along the southeast coast of Greenland. Meanwhile, all three stations on the southwest tip (stations 4270, 4272, 4283) are significantly correlated $(p<0.05)$ with the latitude of the Icelandic low (average $r=0.43$ ) and the EA (average $r=-0.54$ ). The fact that these stations are both correlated with the latitude of the Icelandic low and the EA is supported by results from Moore et al. (2013) showing that the strength of the EA can modulate the latitude of the center of the Icelandic low.

MAR captures interannual variability of AWS DJF precipitation relatively well (average $r=0.7$, average $\left.r^{2}=0.47\right)$, and all seven viable stations had statistically significant correlations with MAR $(p<0.05)$. The strongest correlation was between MAR and station 4270, with $r=0.85$ (Table 4). The average RMSE between viable stations and MAR is $154 \mathrm{~mm}$ w.e. MAR overestimates the available DJF station precipitation, although there is large spatial variability in the degree of overestimation. The mean bias between each station and the nearest MAR grid cell is $127 \mathrm{~mm}$ w.e. during the 1958-2012 period, (Table 4). This is likely a result of large $(20 \mathrm{~km})$ grid cells that smooth the topography, especially near very steep coastal terrain. Despite the model's general tendency to overestimate the absolute values of precipitation, it does capture the variability of precipitation relatively well, and therefore the model is still considered useful in this study.

The strong covariability between DJF precipitation in Tasiilaq and MAR grid cells extends far beyond the grid cell overlying the Tasiilaq station and roughly correspond to the area with significant correlations between MAR DJF precipitation and the Icelandic low (cf. Figs. 6 and 7), reaffirming the linkages between the two. Further, spatially distributed DJF precipitation derived from MAR is statistically significantly correlated with MAR Tasiilaq precipitation over a very large area covering most of SE Greenland and extending $400 \mathrm{~km}$ onto the ice sheet (Fig. 7). Correlations of DJF precipitation between spatially distributed MAR and MAR from the grid cell overlying stations 4390 and 4380 and Tasiilaq respectively also show large spatial correlation of the 4390 and 4380 (Fig. 7). Additionally, these two stations exhibit DJF precipitation variability that is anticorrelated with one large region in NE Greenland and the North Atlantic. Given that Tasiilaq has the longest and most continuous record of precipitation and shows the strongest spatial coherence, we proceed with this station's set of data and consider it to be generally representative of SE precipitation conditions.

\section{d. Circulation and moisture transport}

To look further into the mechanisms of how the longitude of the Icelandic low is related to SE Greenland precipitation, DJF averaged spatial composites of JRA55 reanalysis sea level pressure and moisture transport in years with high $(>1 \mathrm{std})$ and low $(<1 \mathrm{std})$ Icelandic longitude values were analyzed. We find the years when the Icelandic low is in an "extreme east" position to be 1966, 1968, 1969, 1974, 1983, 1984, 1994, 1995, 1999, and 2005. The years with an "extreme west" position of the Icelandic low are 1963, 1964, 1980, 1985, 1987, 1991, 1992, 1996, 2003, and 2006. Sea level pressure during extreme east and west years are distinctly different with the lowest pressure in extreme east years being centered just to the east of the SE coast (Fig. 8a) but centered at the southern tip of Greenland in extreme west years (Fig. 8b). Sea level pressure anomalies show an even stronger geographical east-west difference between extreme east and west longitude years (Figs. 8c,d).

The analysis above (section $4 \mathrm{c}$ ) reveals that the Icelandic low longitude and precipitation at three stations along the SE coast $(4360,4380,4390)$ have negative 


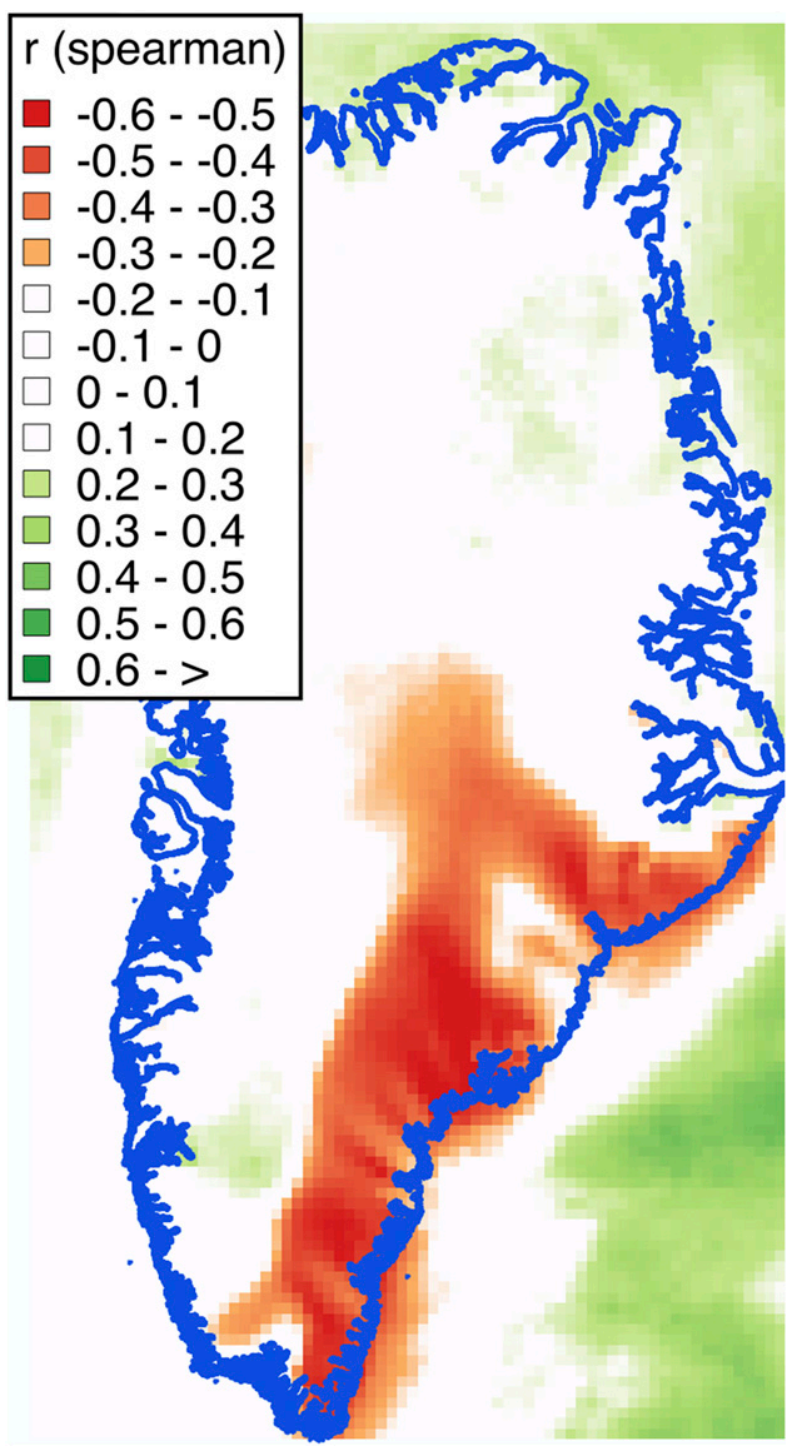

FIG. 6. Spearman correlation with spatially distributed MAR DJF precipitation and Icelandic low longitude. Only statistically significant correlations $(p<0.05)$ are shown

correlation coefficients. Thus, in years when the Icelandic low is in an extreme east position, there is less precipitation in SE Greenland whereas in extreme west Icelandic low years there is more precipitation in the region. Indeed, the moisture transport increases up to $\sim 40 \%$ along the SE coast (up to $\sim 40 \mathrm{~kg} \mathrm{~m}^{-1} \mathrm{~s}^{-1}$ stronger) in extreme west years than in extreme east years (Figs. 9a,b). Additionally, the spatial patterns of anomalies of moisture transport (Figs. 9c,d) show strong movement of moisture toward the SE coast in extreme west years.

\section{e. North Atlantic storm tracks and the Icelandic low}

Composites of storm track density (weighted by storm intensity) in extreme east and extreme west years
(DJF-only averages) show that there are generally more and/or stronger winter storms occurring off of the SE coast of Greenland during years when the Icelandic low is located extremely west, thereby bringing more moisture to the region (Fig. 10). Storm tracks shift east in years when the Icelandic low is extremely east, thereby causing fewer storms to deposit moisture on SE Greenland. The black contours show regions that are statistically significant $(p<0.05)$. This is consistent with the picture in Fig. 10, which shows stronger onshore winds at the SE coast of Greenland in extreme west years. Extreme west years bring more moisture and stronger winds from the ocean to the coast, as well as shifting storm tracks closer to the SE coast of Greenland.

\section{Discussion}

This is the first quantitative study to consider Icelandic low characteristics in explaining SE Greenland winter precipitation, a key parameter in the ice sheet mass balance. Our results demonstrate that among a group of six climate indices and three Icelandic low characteristics, the strongest influence on SE Greenland winter precipitation over the past half century [mean $r \sim-0.48, p<0.01$, e.g., stations 4360 $(r=-0.42), 4380(r=-0.66)$ and $4390(r=-0.37)]$ is the longitude (east-west position) of the Icelandic low. Correlations between the Icelandic low longitude and DJF precipitations tapers off north of the Tasiilaq station (station 4350) and on the west side of the south tip of Greenland (stations 4270, 4272, 4283). This result reaffirms the importance and utility of considering the Icelandic low and NAO as independent metrics to explain North Atlantic climate, as stated in Bakalian et al. (2007). Previous work has already shown that Icelandic low characteristics control important climate characteristics of the North Atlantic region, including the position of the north wall of the Gulf Stream (Hameed and Piontkovski 2004) and the formation of the Greenland tip jets (Bakalian et al. 2007). With this study, that list is augmented with the influence on SE Greenland precipitation.

Our finding that the Icelandic low longitude is a strong control of SE Greenland precipitation is robust even when shorter time periods (e.g., winter decadal windows) are considered. In the analysis of different periods (e.g., correlations calculated after applying the 10-yr moving window; Fig. 5) the Icelandic low longitude position stands out with significant correlations in $43 \%$ of the $10-\mathrm{yr}$ moving average periods compared to $21 \%$ for the GBI, the second highest result for all the six indices and three characteristics. Significant correlations with longitude are always negatively correlated with SE 
TABLE 4. Correlation statistics (on DJF data) between the viable DMI stations and MAR at the nearest grid cell to each station. The Sig. means Significance.

\begin{tabular}{cccccrr}
\hline \hline Station ID & $\begin{array}{c}\text { \% data coverage } \\
\text { (from } 1958 \text { to 2012) }\end{array}$ & $\begin{array}{c}\text { Correlation with MAR at } \\
\text { nearest grid cell }(r \text { value })\end{array}$ & $\begin{array}{c}\text { Sig. of correlation with } \\
\text { MAR }(p \text { value })\end{array}$ & $R^{2}$ value & RMSE mm w.e. & Bias mm w.e. \\
\hline 4360 & 98 & 0.77 & $7 \times 10^{-12}$ & 0.60 & 141 \\
4390 & 76 & 0.52 & $5 \times 10^{-4}$ & 0.27 & 305 \\
4380 & 38 & 0.71 & $3 \times 10^{-4}$ & 0.51 & 124 & 265 \\
4350 & 38 & 0.66 & $1 \times 10^{-3}$ & 0.43 & 315 \\
4270 & 89 & 0.85 & $1 \times 10^{-14}$ & 0.72 & 84 \\
4272 & 95 & 0.71 & $5 \times 10^{-9}$ & 0.50 & 40 \\
4283 & 40 & 0.52 & $1 \times 10^{-2}$ & 0.27 & 68 & 89 \\
Mean & & $\mathbf{0 . 7}$ & & $\mathbf{0 . 4 7}$ & $\mathbf{1 5 4}$ \\
\hline
\end{tabular}

Greenland precipitation. The second most important index, the GBI, is significantly negatively correlated during the late 1960s and early 1970s, and again briefly during the late 2000s, but during the late 1990s it becomes positively correlated. Hanna et al. (2013) perform a similar analysis on summer Greenland temperature, finding unstable correlations, and indeed changing sign, for the Tasiilaq record.

Previous attempts to determine controls of Greenland precipitation have largely focused on associations with the NAO, GBI, and AO; however, correlations are generally weak or highly dependent on the time frame considered. For example, Hanna et al. (2006) found no significant correlation with December-March precipitation in SE Greenland and the NAO from 1959 to 2004, but they did find significant correlations when considering smaller time frames of 1958-78 $(r=0.31)$ and 1979-98 $(r=-0.56)$. On the contrary, using an empirical orthogonal function analysis, Mernild et al. (2015) found that precipitation from 1890 to 2000 is linked to the NAO and AMO instantaneously, and with an $\sim 6$-yr lag to the GBI. Finally, Appenzeller et al. (1998a) showed that snow accumulation is a good proxy for the NAO index, but this only holds for western Greenland and does not show strong influence on eastern Greenland precipitation.

The skill by which climate indices predict Greenland precipitation depends on how well they function as proxies for the actual processes controlling winter precipitation in SE Greenland. This is determined by a complex interplay of cold downslope katabatic winds, near-surface northeasterly winds along the coast, steering-level winds associated with the presence of the

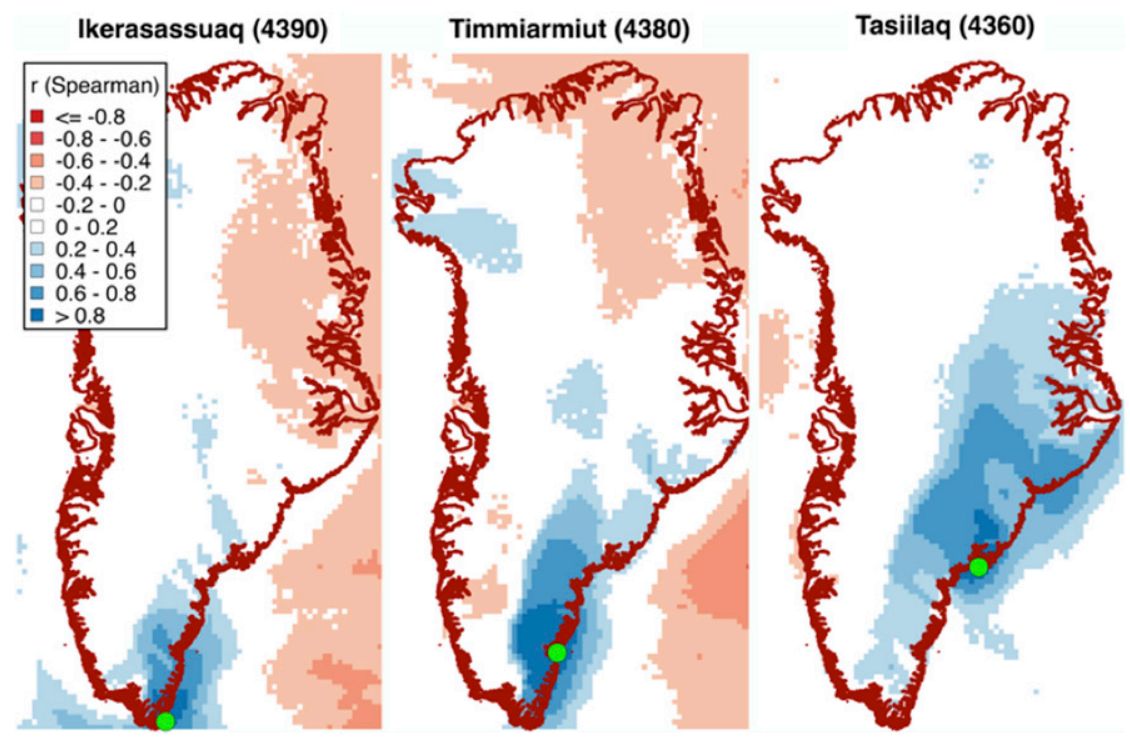

FIG. 7. Spearman correlation with DJF precipitation from spatially distributed MAR and MAR from the grid cell overlying stations Ikerassuaq, Timmiarmiut, and Tasiilaq (station locations shown with green circles). Only statistically significant correlations $(p<0.05)$ are shown. 


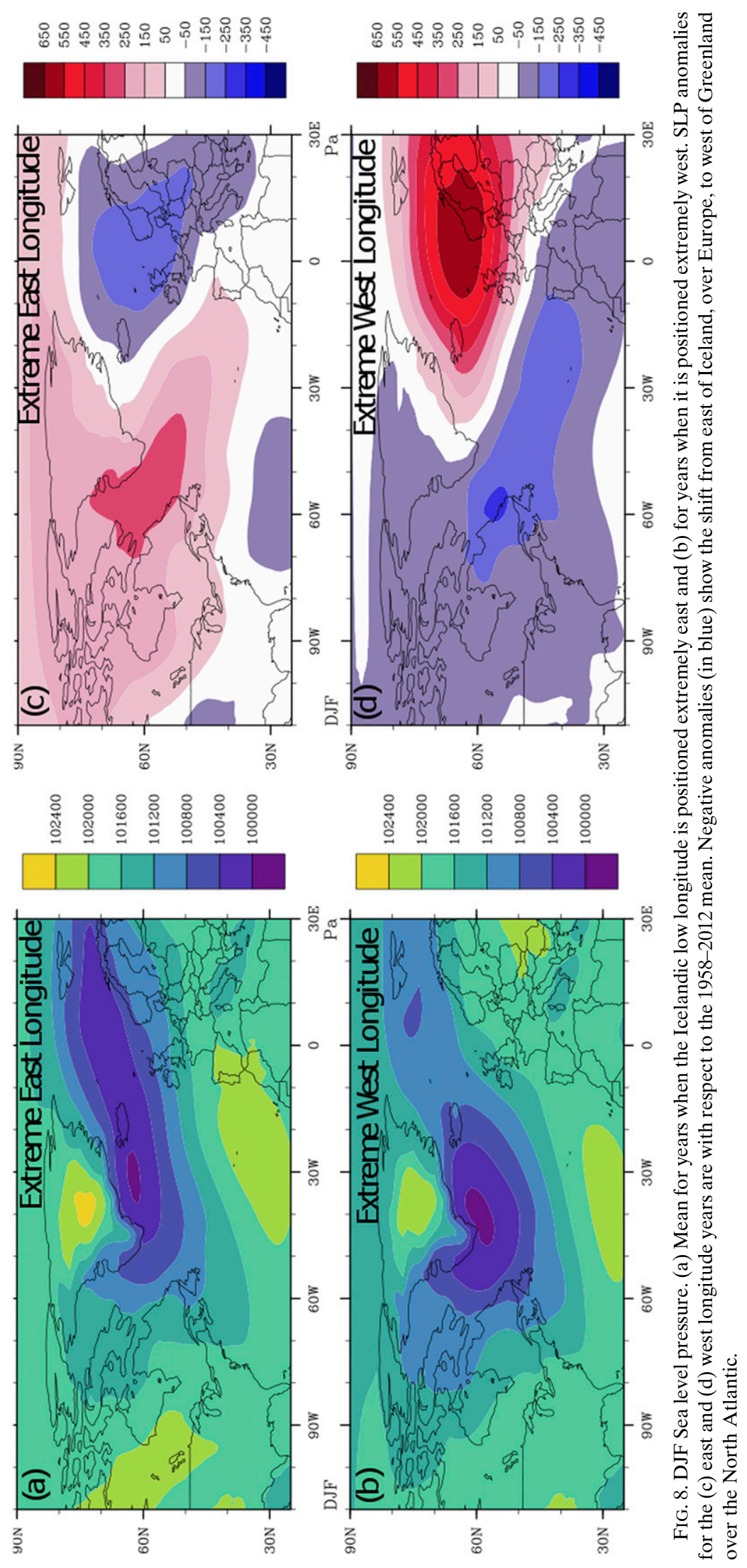



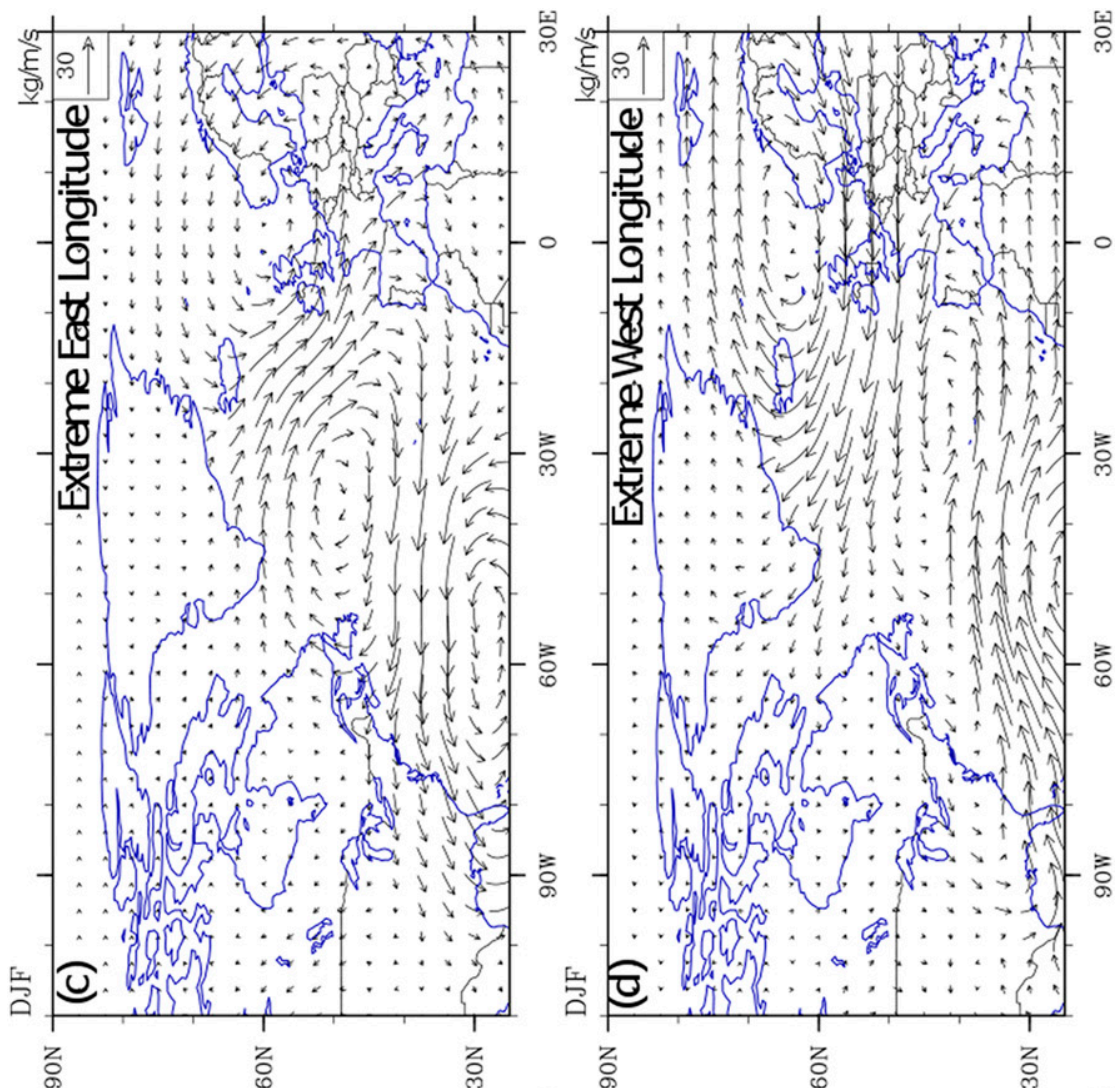

㞤
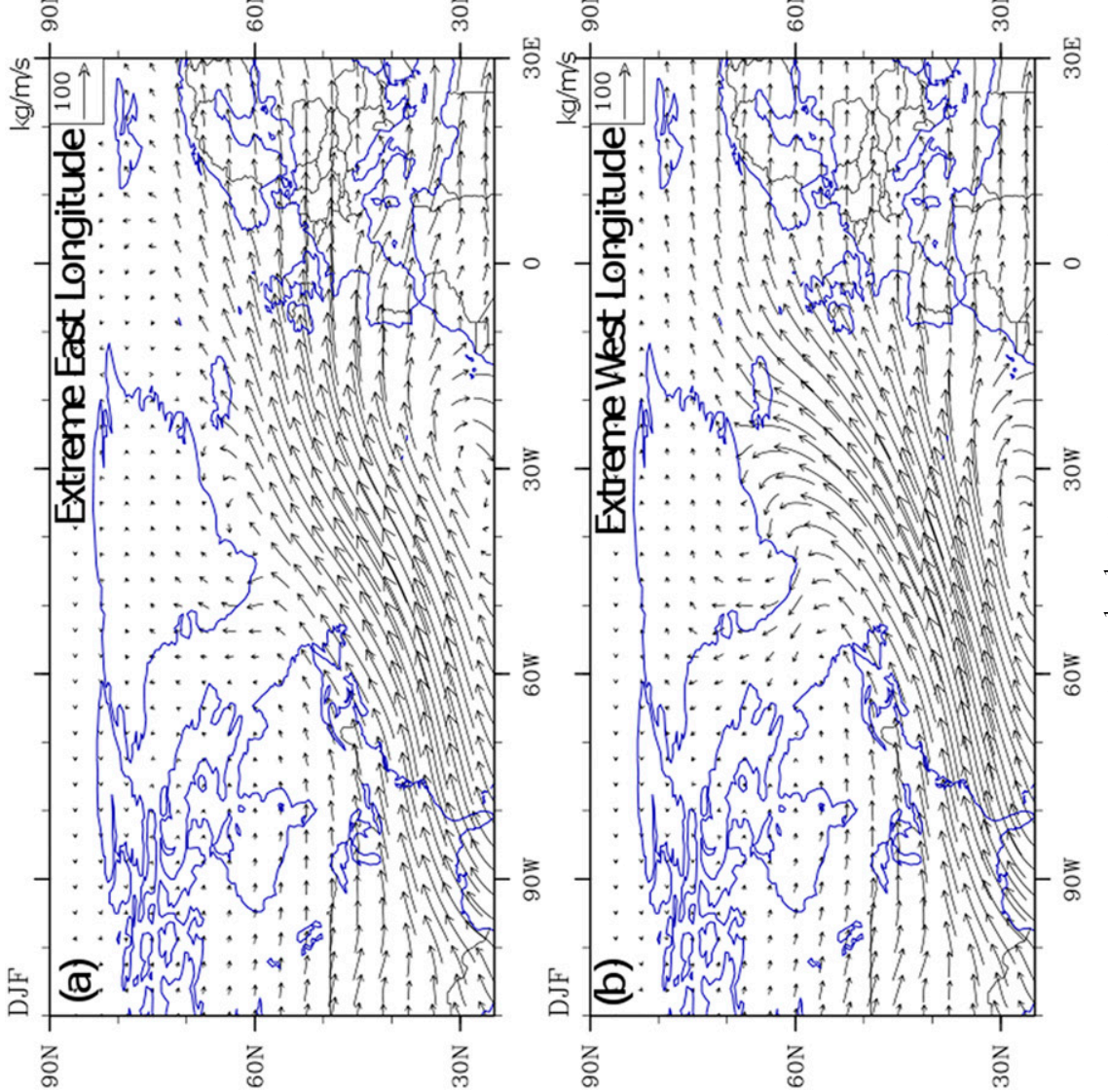

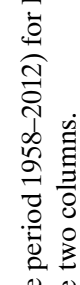

$\stackrel{5}{\Xi}$

ठे

茖

들

층 은

政

잉

일

क्ये

은

㝴

$\stackrel{2}{2}$

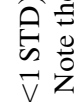

ฟैำ

\&

청 음

อ.

클

ลิ

究

范

है है

ถี

离客

形弯

$-10$

'ह

$\ddot{y}$

동 중

들

늘

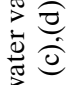

家 


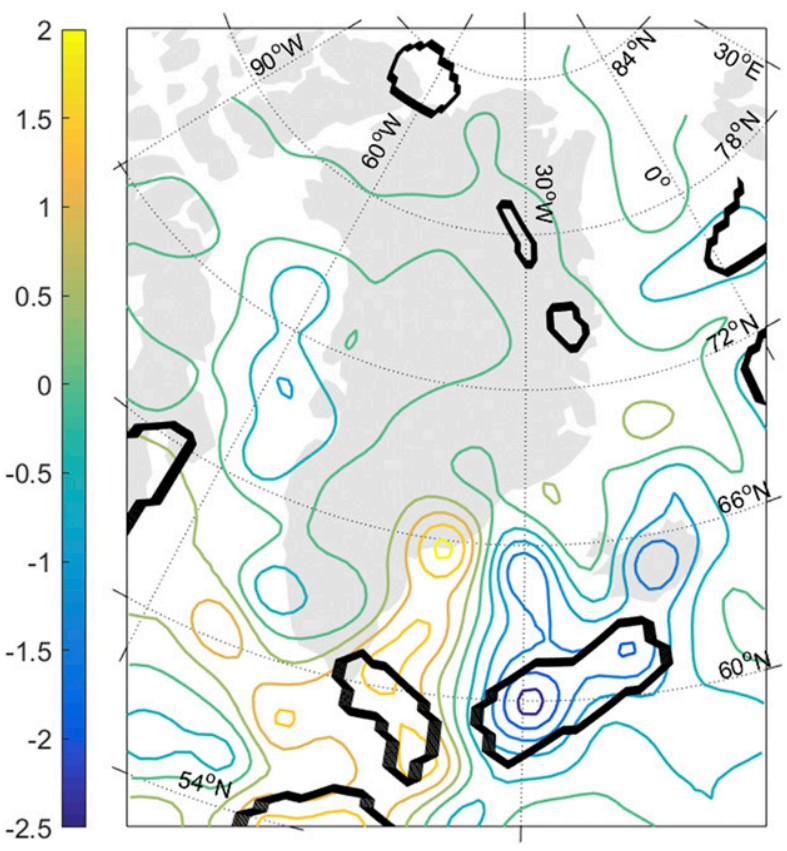

FIG. 10. Colored contours show storm track density (number of storms per unit area) weighted by the local Laplacian of pressure (a measure of intensity) for the difference between the extreme west (low longitude) years and extreme east (high longitude) years. Positive values indicate an increase in density (intensity) in extreme west years, and negative values for extreme east years. Black contours show regions that are statistically significant at the $5 \%$ level.

Icelandic low, distance from the moisture source, and steep coastal topography, which enhances orographic precipitation (Gorter et al. 2013; Hanna et al. 2006). High-intensity, short-lived events such as atmospheric rivers and winter cyclones can also play a role in moisture transport to Greenland (Liu and Barnes 2015; Mattingly et al. 2016; Serreze et al. 1997). While most of these processes were not considered directly in this study, the position of the Icelandic low can explain up to $32 \%$ (Tasiilaq; December), 19\% (station 4390; October), and $49 \%$ (station 4380; February) of the monthly precipitation variability caused by them. The temporal variation in the strength of the correlation in Icelandic low longitude and DJF precipitation, which is strongest in the 1960s and 1990s and weak in the 1980s and 2000s, may be traced back to decadal variability in some of the process mentioned above but further study of this is needed.

The mechanism by which the longitude of the Icelandic low influences SE Greenland precipitation is at least twofold. When the Icelandic low is in an extreme east position, there is less precipitation as a result of weaker atmospheric moisture transport to the SE coast from inconsistent directions (Fig. 9). When the Icelandic low is extremely west, larger amounts of more moisture are transported to the SE coast of Greenland. Furthermore, the mechanism of moisture transport we identified (Fig. 9) is robust and consistent throughout the entire study period. This is shown by the significant correlations between Icelandic low longitude and SE Greenland precipitation (here represented by Tasiilaq station) in $43 \%$ of the 10 -yr moving average periods (Fig. 5). Furthermore, when the Icelandic low is extremely west, winter storm tracks are pushed nearer to the SE coast of Greenland (Fig. 10), bringing higher amounts of precipitation, consistent with the upper-level moisture transport in Fig. 9. In extremely east years when precipitation in SE Greenland is low, the storm tracks are pulled away from the Greenland coast and farther east into the North Atlantic. Ultimately, the Icelandic low's longitude does not capture all processes driving SE Greenland winter precipitation, but it explains a significant amount of the precipitation variability ( $r^{2}$ is between $19 \%$ and $49 \%$ for the three viable stations on the SE coast) through changes in moisture advection patterns and cyclone tracks. The Icelandic low position should therefore be considered together with the other climate indices in studies of SE Greenland precipitation and ice sheet mass balance.

\section{Conclusions}

This paper shows that the position of the Icelandic low longitude (e.g., east-west location) better explains SE Greenland winter precipitation than six more commonly used climate indices (e.g., the NAO, AO, AMO, GBI, EA, and SCA) with $r$ values as high as $|r|=0.42$ (compared to less than 0.28 for the other indices). The Icelandic low sets up moist southeasterly winds over SE Greenland when it is far to the west, and drier $\left(\sim 0.5 \mathrm{~kg} \mathrm{~m}^{-2}\right)$, weaker winds $\left(\sim 5 \mathrm{~m} \mathrm{~s}^{-1}\right)$ over SE Greenland when it is far to the east, thereby providing a mechanism for the strong relationship. Furthermore, the east-west position of the Icelandic low controls storm track locations and thereby precipitation in SE Greenland. Storms move farther west (toward the SE coast of Greenland) and deposit more precipitation on the SE coast of Greenland when the low is farther west and vice versa when the low is farther east. Given the importance of SE Greenland winter precipitation in the overall ice sheet mass balance, the Icelandic low characteristics should be considered together with the more commonly used indices when the ice sheet mass balance is investigated.

Acknowledgments. M. Berdahl and A. Rennermalm were funded by National Science Foundation (NSF) Grant PLR-1304805 and by NASA Interdisciplinary Sciences 
Grant NNX14AD98G. A. Hamman, J. Mioduszweski, J. Stroeve, T. Koyama, and M. Tedesco were funded by NSF Grant PLR-1304805. S T. Mote was funded by NASA Interdisciplinary Sciences Grant NNX14AD98G. J. McConnell was funded by a number of NSF and NASA grants to develop the ice core data used in this study. The open source software products QGIS and NCAR command language were used in data analysis and map making.

\section{REFERENCES}

Andersen, M. L., and Coauthors, 2015: Basin-scale partitioning of Greenland ice sheet mass balance components (2007-2011). Earth Planet. Sci. Lett., 409, 89-95, https://doi.org/10.1016/ j.epsl.2014.10.015.

Appenzeller, C., J. Schwander, S. Sommer, and T. Stocker, 1998a: The North Atlantic Oscillation and its imprint on precipitation and ice accumulation in Greenland. Geophys. Res. Lett., 25, 1939-1942, https://doi.org/10.1029/98GL01227.

_, T. Stocker, and M. Anklin, 1998b: North Atlantic oscillation dynamics recorded in Greenland ice cores. Science, 282, 446449, https://doi.org/10.1126/science.282.5388.446.

Arguez, A., J. J. O'Brien, and S. R. Smith, 2009: Air temperature impacts over eastern North America and Europe associated with low-frequency North Atlantic SST variability. Int. J. Climatol., 29, 1-10, https://doi.org/10.1002/joc.1700.

Bakalian, F., S. Hameed, and R. Pickart, 2007: Influence of the Icelandic low latitude on the frequency of Greenland tip jet events: Implications for Irminger Sea convection. J. Geophys. Res., 112, C04020, https://doi.org/10.1029/2006JC003807.

Bales, R. C., and Coauthors, 2009: Annual accumulation for Greenland updated using ice core data developed during 2000-2006 and analysis of daily coastal meteorological data. J. Geophys. Res., 114, D06116, https://doi.org/10.1029/ 2008JD011208.

Bindschadler, R. A., and Coauthors, 2013: Ice-sheet model sensitivities to environmental forcing and their use in projecting future sea level (the SeaRISE project). J. Glaciol., 59, 195-224, https://doi.org/10.3189/2013JoG12J125.

Box, J. E., 2013: Greenland ice sheet mass balance reconstruction. Part II: Surface mass balance (1840-2010). J. Climate, 26, 6974-6989, https://doi.org/10.1175/JCLI-D-12-00518.1.

Bromwich, D. H., Q. Chen, Y. Li, and R. I. Cullather, 1999: Precipitation over Greenland and its relation to the North Atlantic Oscillation. J. Geophys. Res., 104, 22 103-22 115, https:// doi.org/10.1029/1999JD900373.

Burgess, E. W., R. R. Forster, J. E. Box, E. Mosley-Thompson, D. H. Bromwich, R. C. Bales, and L. C. Smith, 2010: A spatially calibrated model of annual accumulation rate on the Greenland ice sheet (1958-2007). J. Geophys. Res., 115, F02004, https://doi.org/10.1029/2009JF001293.

Cappelen, J., Ed., 2014: Greenland-DMI historical climate data collection 1784-2013. DMI Tech. Rep. 14-04, 90 pp., https:// www.dmi.dk/fileadmin/user_upload/Rapporter/TR/2014/tr1404.pdf. [Data available at http://www.dmi.dk/fileadmin/user_ upload/Rapporter/TR/2014/tr14-04.zip.]

Chen, L., Johannessen, O. M., H. Wang, and A. Ohmura, 2011: Accumulation over the Greenland ice sheet as represented in reanalysis data. Adv. Atmos. Sci., 28, 1030-1038, https:// doi.org/10.1007/s00376-010-0150-9.
Cogley, J. G., 2004: Greenland accumulation: An error model. J. Geophys. Res., 109, D18101, https://doi.org/10.1029/ 2003JD004449.

Dawson, A. G., K. Hickey, P. A. Mayewski, and A. Nesje, 2007: Greenland (GISP2) ice core and historical indicators of complex North Atlantic climate changes during the fourteenth century. Holocene, 17, 427-434, https://doi.org/10.1177/ 0959683607077010.

Ebita, A., and Coauthors, 2011: The Japanese 55-year Reanalysis JRA-55: An interim report. SOLA, 7, 149-152, https://doi.org/ 10.2151/sola.2011-038.

Enderlin, E. M., I. M. Howat, S. Jeong, M.-J. Noh, J. H. van Angelen, and M. R. van den Broeke, 2014: An improved mass budget for the Greenland ice sheet. Geophys. Res. Lett., 41, 866-872, https://doi.org/10.1002/2013GL059010.

Enfield, D. B., A. M. Mestas-Nuñez, and P. J. Trimble, 2001: The Atlantic multidecadal oscillation and its relationship to rainfall and river flows in the continental U.S. Geophys. Res. Lett., 28, 2077-2080, https://doi.org/10.1029/2000GL012745.

Fettweis, X., 2007: Reconstruction of the 1979-2006 Greenland ice sheet surface mass balance using the regional climate model MAR. Cryosphere, 1, 21-40, https://doi.org/10.5194/ tc-1-21-2007.

_ M. Tedesco, M. van den Broeke, and J. Ettema, 2011: Melting trends over the Greenland ice sheet (1958-2009) from spaceborne microwave data and regional climate models. Cryosphere, 5, 359-375, https://doi.org/10.5194/tc-5-359-2011.

_ , B. Franco, M. Tedesco, J. H. van Angelen, J. T. M. Lenaerts, M. R. van den Broeke, and H. Gallée, 2013: Estimating the Greenland ice sheet surface mass balance contribution to future sea level rise using the regional atmospheric climate model MAR. Cryosphere, 7, 469-489, https://doi.org/10.5194/tc-7-469-2013.

— , and Coauthors, 2017: Reconstructions of the 1900-2015 Greenland ice sheet surface mass balance using the regional climate MAR model. Cryosphere, 11, 1015-1033, https:// doi.org/10.5194/tc-11-1015-2017.

Franco, B., X. Fettweis, C. Lang, and M. Erpicum, 2012: Impact of spatial resolution on the modelling of the Greenland ice sheet surface mass balance between 1990-2010, using the regional climate model MAR. Cryosphere, 6, 695-711, https://doi.org/ 10.5194/tc-6-695-2012.

Gallée, H., 1995: Simulation of the mesocyclonic activity in the Ross Sea, Antarctica. Mon. Wea. Rev., 123, 2051-2069, https:// doi.org/10.1175/1520-0493(1995)123<2051:SOTMAI>2.0.CO;2.

__ , and G. Schaves, 1994: Development of a three-dimensional meso- $\gamma$ primitive equation model: Katabatic winds simulation in the area of Terra Nova Bay, Antarctica. Mon. Wea. Rev., 122, 671-685, https://doi.org/10.1175/1520-0493(1994)122<0671: DOATDM $>2.0 . \mathrm{CO} ; 2$.

- V. Peyaud, and I. Goodwin, 2005: Simulation of the net snow accumulation along the Wilkes Land transect, Antarctica, with a regional climate model. Ann. Glaciol., 41, 17-22, https:// doi.org/10.3189/172756405781813230.

Gardner, A. S., and Coauthors, 2013: A reconciled estimate of glacier contributions to sea level rise: 2003 to 2009. Science, 340, 852-857, https://doi.org/10.1126/science.1234532.

Gorter, W., J. H. van Angelen, J. T. M. Lenaerts, and M. R. van den Broeke, 2013: Present and future near-surface wind climate of Greenland from high resolution regional climate modeling. Climate Dyn., 42, 1595-1611, https://doi.org/ 10.1007/s00382-013-1861-2.

Hameed, S., and S. Piontkovski, 2004: The dominant influence of the Icelandic low on the position of the Gulf Stream north 
wall. Geophys. Res. Lett., 31, L09303, https://doi.org/10.1029/ 2004 GL019561.

Hanna, E., J. McConnell, S. Das, J. Cappelen, and A. Stephens, 2006: Observed and modeled Greenland ice sheet snow accumulation, 1958-2003, and links with regional climate forcing. J. Climate, 19, 344-358, https://doi.org/10.1175/ JCLI3615.1.

_ J. Cappelen, X. Fettweis, P. Huybrechts, A. Luckman, and M. H. Ribergaard, 2009: Hydrologic response of the Greenland ice sheet: The role of oceanographic warming. Hydrol. Processes, 23, 7-30, https://doi.org/10.1002/hyp.7090.

_, J. M. Jones, J. Cappelen, S. H. Mernild, L. Wood, K. Steffen, and P. Huybrechts, 2013: The influence of North Atlantic atmospheric and oceanic forcing effects on 1900-2010 Greenland summer climate and ice melt/runoff. Int. J. Climatol., 33, 862-880, https://doi.org/10.1002/joc.3475.

Hauke, J., and T. Kossowski, 2011: Comparison of values of Pearson's and Spearman's correlation coefficient on the same sets of data. Quaest. Geogr., 30, 87-93, https://doi.org/10.2478/ v10117-011-0021-1.

Hines, K. M., and D. H. Bromwich, 2008: Development and testing of polar Weather Research and Forecasting (WRF) model. Part I: Greenland ice sheet meteorology. Mon. Wea. Rev., 136, 1971-1989, https://doi.org/10.1175/2007MWR2112.1.

Hurrell, J. W., 1995: Decadal trends in the North Atlantic Oscillation: Regional temperatures and precipitation. Science, 269, 676-679, https://doi.org/10.1126/science.269.5224.676.

—_, Y. Kushnir, G. Ottersen, and M. Visbeck, 2003: The North Atlantic Oscillation: Climatic Significance and Environmental Impact. Geophys. Monogr., Vol. 134, Amer. Geophys. Union, 279 pp.

Jones, P. D., T. Jónsson, and D. Wheeler, 1997: Extension to the North Atlantic Oscillation using early instrumental pressure observations from Gibraltar and south-west Iceland. Int. J. Climatol., 17, 1433-1450, https://doi.org/10.1002/(SICI) 1097-0088(19971115)17:13<1433::AID-JOC203>3.0.CO;2-P.

Jordi, A., and S. Hameed, 2009: Influence of the Icelandic low on the variability of the surface air temperature in the Gulf of Lion: Implications for Intermediate Water formation. J. Phys. Oceanogr., 39, 3228-3232, https://doi.org/10.1175/ 2009JPO4194.1.

Kalnay, E. M., and Coauthors, 1996: The NCEP/NCAR 40-Year Reanalysis Project. Bull. Amer. Meteor. Soc., 77, 437-471, https:// doi.org/10.1175/1520-0477(1996)077<0437:TNYRP>2.0.CO;2.

Koenig, L. S., and Coauthors, 2016: Annual Greenland accumulation rates (2009-2012) from airborne snow radar. Cryosphere, 10, 1739-1752, https://doi.org/10.5194/ tc-10-1739-2016.

Koyama, T., J. Stroeve, J. Cassano, and A. Crawford, 2017: Sea ice loss and Arctic cyclone activity from 1979 to 2014. J. Climate, 30, 4735-4754, https://doi.org/10.1175/JCLI-D-16-0542.1.

Lefebre, F., X. Fettweis, H. Gallée, J. P. Van Ypersele, P. Marbaix, W. Greuell, and P. Calanca, 2005: Evaluation of a highresolution regional climate simulation over Greenland. Climate Dyn., 25, 99-116, https://doi.org/10.1007/s00382-005-0005-8.

Lenaerts, J., M. van den Broeke, J. van Angelen, E. van Meijgaard, and S. Déry, 2012: Drifting snow climate of the Greenland ice sheet: A study with a regional climate model. Cryosphere, $\mathbf{6}$, 891-899, https://doi.org/10.5194/tc-6-891-2012.

Li, J., C. Sun, and F. F. Jin, 2013: NAO implicated as a predictor of Northern Hemisphere mean temperature multidecadal variability. Geophys. Res. Lett., 40, 5497-5502, doi:10.1002/ 2013 GL057877.
Liu, C., and E. A. Barnes, 2015: Extreme moisture transport into the Arctic linked to Rossby wave breaking. J. Geophys. Res. Atmos., 120, 3774-3788, https://doi.org/10.1002/ 2014JD022796.

Mattingly, K. S., C. A. Ramseyer, J. J. Rosen, T. L. Mote, and R. Muthyala, 2016: Increasing water vapor transport to the Greenland Ice Sheet revealed using self-organizing maps. Geophys. Res. Lett., 43, 9250-9258, doi:10.1002/ 2016 GL070424.

Mernild, S. H., and Coauthors, 2015: Greenland precipitation trends in a long-term instrumental climate context (18902012): Evaluation of coastal and ice core records. Int. J. Climatol., 35, 303-320, https://doi.org/10.1002/joc.3986.

Moore, G. W. K., R. S. Pickart, and I. A. Renfrew, 2011: Complexities in the climate of the subpolar North Atlantic: A case study from the winter of 2007. Quart. J. Roy. Meteor. Soc., 137, 757-767, https://doi.org/10.1002/qj.778.

, I. A. Renfrew, and R. S. Pickart, 2013: Multidecadal mobility of the North Atlantic Oscillation. J. Climate, 26, 2453-2466, https://doi.org/10.1175/JCLI-D-12-00023.1.

Mosley-Thompson, E., C. Readinger, P. Craigmile, L Thompson, and C. Calder, 2005: Regional sensitivity of Greenland precipitation to NAO variability. Geophys. Res. Lett., 32, L24707, https://doi.org/10.1029/2005GL024776.

Murray, R. J., and I. Simmonds, 1991: A numerical scheme for tracking cyclone centres from digital data. Part I: Development and operation of the scheme. Aust. Meteor. Mag., 39 (3), $155-166$.

Ohmura, A., and N. Reeh, 1991: New precipitation and accumulation maps for Greenland. J. Glaciol., 37, 140-148, https:// doi.org/10.1017/S0022143000042891.

Petersen, G. N., I. A. Renfrew, and G. W. K. Moore, 2009: An overview of barrier winds off southeastern Greenland during the Greenland Flow Distortion experiment. Quart. J. Roy. Meteor. Soc., 135, 1950-1967, https://doi.org/10.1002/ qj. 455.

Reijmer, C. H., M. R. van den Broeke, X. Fettweis, J. Ettema, and L. B. Stap, 2012: Refreezing on the Greenland ice sheet: A comparison of parameterizations. Cryosphere, 6, 743-762, https://doi.org/10.5194/tc-6-743-2012.

Renfrew, I. A., and Coauthors, 2008: The Greenland Flow Distortion Experiment. Bull. Amer. Meteor. Soc., 89, 1307-1324, https://doi.org/10.1175/2008BAMS2508.1.

Rignot, E., I. Velicogna, M. van den Broeke, A. Monaghan, and J. Lenaerts, 2011: Acceleration of the contribution of the Greenland and Antarctic ice sheets to sea level rise. Geophys. Res. Lett., 38, L05503, https://doi.org/10.1029/2011GL046583.

Sanchez-Franks, A., S. Hameed, and R. E. Wilson, 2016:The Icelandic low as a predictor of the Gulf Stream north wall position. J. Phys. Oceanogr., 46, 817-826, https://doi.org/10.1175/ JPO-D-14-0244.1.

Serreze, M. C., and A. P. Barrett, 2008: The summer cyclone maximum over the central Arctic Ocean. J. Climate, 21, 10481065, https://doi.org/10.1175/2007JCLI1810.1.

, F. Carse, R. G. Barry, and J. C. Rogers, 1997: Icelandic low cyclone activity: Climatological features, linkages with the NAO, and relationships with recent changes in the Northern Hemisphere circulation. J. Climate, 10, 453-464, https://doi.org/ 10.1175/1520-0442(1997)010<0453:ILCACF > 2.0.CO;2.

Sun, C., J. Li, and F.-F. Jin, 2015: A delayed oscillator model for the quasi-periodic multidecadal variability of the NAO. Climate Dyn., 45, 2083-2099, https://doi.org/10.1007/ s00382-014-2459-z. 
Tedesco, M., X. Fettweis, T. Mote, J. Wahr, P. Alexander, J. Box, and B. Wouters, 2013: Evidence and analysis of 2012 Greenland records from spaceborne observations, a regional climate model and reanalysis data. Cryosphere, 7, 615-630, https:// doi.org/10.5194/tc-7-615-2013.

van den Broeke, M. R., and Coauthors, 2009: Partitioning recent Greenland mass loss. Science, 326, 984-986, https://doi.org/ 10.1126/science.1178176.

, E. M. Enderlin, I. M. Howat, P. Kuipers Munneke, B. P. Y. Noël, W. J. van de Berg, E. van Meijgaard, and B. Wouters, 2016: On the recent contribution of the Greenland ice sheet to sea level change. Cryosphere, 10, 1933-1946, https://doi.org/ 10.5194/tc-10-1933-2016.
Vaughan, D. G., and Coauthors, 2013: Observations: Cryosphere. Climate Change 2013: The Physical Science Basis, T. F. Stocker et al., Eds., Cambridge University Press, 317-382.

Velicogna, I., 2009: Increasing rates of ice mass loss from the Greenland and Antarctic ice sheets revealed by GRACE. Geophys. Res. Lett., 36, L19503, https://doi.org/10.1029/ 2009GL040222.

Wilks, D. S., 2011: Statistical Methods in the Atmospheric Sciences. Elsevier Science, $676 \mathrm{pp}$.

Yang, D., S. Ishida, B. E. Goodison, and T. Gunther, 1999: Bias correction of daily precipitation measurements for Greenland. J. Geophys. Res., 104, 6171-6181, https://doi.org/10.1029/ 1998JD200110. 